City University of New York (CUNY)

CUNY Academic Works

\title{
An Innovative Approach for Integrating Mandatory, Longitudinal Spirituality Training into the Medical School Curriculum
}

\author{
David W. Fleenor \\ Mount Sinai School of Medicine \\ Holly G. Atkinson \\ CUNY City College \\ Reena Karani \\ Mount Sinai School of Medicine \\ Susan Lerner \\ Mount Sinai School of Medicine \\ Staci Leisman \\ Mount Sinai School of Medicine
}

See next page for additional authors

\section{How does access to this work benefit you? Let us know!}

More information about this work at: https://academicworks.cuny.edu/cc_pubs/858

Discover additional works at: https://academicworks.cuny.edu

This work is made publicly available by the City University of New York (CUNY).

Contact: AcademicWorks@cuny.edu 
Authors

David W. Fleenor, Holly G. Atkinson, Reena Karani, Susan Lerner, Staci Leisman, and Deborah Marin 


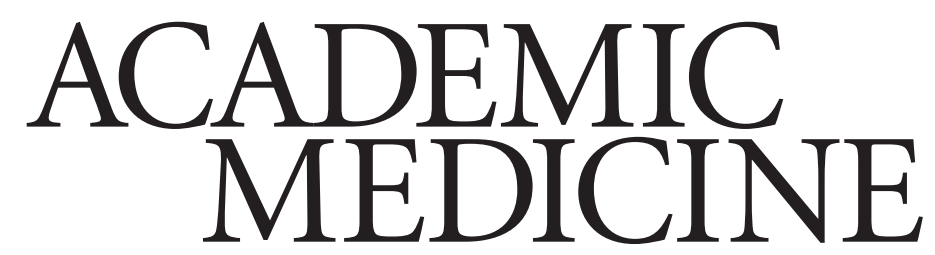

Journal of the Association of American Medical Colleges

Uncomposed, edited manuscript published online ahead of print.

This published ahead-of-print manuscript is not the final version of this article, but it may be cited and shared publicly.

Author: Fleenor David W. STM; Atkinson Holly G. MD; Karani Reena MD, MHPE; Lerner Susan MD; Leisman Staci MD; Marin Deborah MD

Title: An Innovative Approach for Integrating Mandatory, Longitudinal Spirituality Training Into the Medical School Curriculum

DOI: $\quad$ 10.1097/ACM.0000000000004494 


\section{Academic Medicine}

DOI: 10.1097/ACM.0000000000004494

An Innovative Approach for Integrating Mandatory, Longitudinal Spirituality Training Into the Medical School Curriculum

David W. Fleenor, STM, Holly G. Atkinson, MD, Reena Karani, MD, MHPE, Susan Lerner, MD, Staci Leisman, MD, and Deborah Marin, MD

D.W. Fleenor is assistant professor, Department of Medical Education, and director of education, Center for Spirituality and Health, Icahn School of Medicine at Mount Sinai, New York, New York: ORCID: https://orcid.org/0000-0002-6508-9910.

H.G. Atkinson is affiliate clinical professor, Department of Medical Education and Academic Affairs, CUNY School of Medicine, New York, NY: ORCID: https://orcid.org/0000-0001-90666460.

R. Karani is director, Institute for Medical Education, and professor of medical education, medicine, and geriatrics and palliative care, Icahn School of Medicine at Mount Sinai, New York, New York: ORCID: https://orcid.org/0000-0002-6424-1626.

S. Lerner is associate professor of surgery and medical education, Icahn School of Medicine at Mount Sinai, New York, New York: ORCID: https://orcid.org/0000-0001-6159-4541.

S. Leisman is associate professor of medicine, nephrology, and medical education, Icahn School of Medicine at Mount Sinai, New York, New York: ORCID: https://orcid.org/0000-0003-49184149.

D. Marin is George C. Blumenthal professor of psychiatry, associate professor of geriatrics and palliative medicine, and director, Center for Spirituality and Health, Icahn School of Medicine at Mount Sinai, New York, New York: ORCID: https://orcid.org/0000-0001-5794-6997 
Correspondence should be addressed to David Fleenor, Center for Spirituality and Health, Icahn School of Medicine at Mount Sinai, One Gustave L. Levy Place, Box 1036, New York, NY 10029, telephone: (212) 241-5280; email: david.fleenor@mountsinai.org.

Acknowledgments: The authors wish to thank David Muller, Ed Poliandro, Joseph Truglio, Jennifer Weintraub, and Beverly Forsyth for reviewing and commenting on this manuscript. The authors also wish to express gratitude to Joanne Hojsak and Alefiyah Malbari who, in addition to reviewing and commenting on the manuscript, participated in data collection. Finally, the authors would like to convey appreciation to Patricia Palmer and Vansh Sharma for their role in data analysis.

Funding/Support: None reported.

Other disclosures: None reported.

Ethical approval: The Program for the Protection of Human Subjects at the Mount Sinai Health System granted institutional review board exemption (HS\# 20-01216) for this project on October

$8,2020$. 


\section{Abstract \\ Problem}

Most Americans indicate they are religious and/or spiritual and wish to have their beliefs taken into account when engaging with health care providers, yet gaps in medical education and health care practice remain. To underscore the importance of spirituality as a significant social determinant of health, a team at the Icahn School of Medicine at Mount Sinai in New York developed mandatory spirituality and health training for students integrated into all 4 years of the undergraduate medical education curriculum.

\section{Approach}

From 2014 to 2020, a small group of faculty took an innovative approach, launching the initiative and expanding the team by engaging interprofessional faculty and staff from across the institution. The team used an iterative process to integrate 4 distinct modules into 4 existing courses, spanning the four years of medical school.

\section{Outcomes}

The majority of students found that the spirituality and health curriculum was valuable to training and professional development. They appreciated the importance of patients' spiritual needs; valued learning about the role chaplains play in patient care and how initiate a consult; and indicated they intended to integrate spiritual history-taking in their patient care. With respect to process, 3 key factors - establishing an interprofessional team, working through an iterative process, and integrating the curriculum into existing courses - were critical to designing and implementing the modules. 


\section{Next steps}

The team aims to expand and improve the curriculum by linking learning to specific standardized competencies as well as developing more specific performance assessments to demonstrate achievement of competencies. Professional development efforts will be enhanced so faculty can better model and reinforce the integration of spirituality into health care practices, and expand the curriculum on spirituality and health into graduate medical education. 


\section{Problem}

Just over half (54\%) of Americans indicate they are religious, while about one-quarter (27\%) report being spiritual but not religious. ${ }^{1}$ Fewer than $20 \%$ say they are neither religious nor spiritual. Thus, for most Americans, religion and/or spirituality have some degree of importance in their lives and many people base medical decisions on their beliefs. Research indicates that integrating spirituality into health care improves patients' satisfaction and end-of-life decision making, among other important outcomes. ${ }^{2}$ Yet although $41 \%-83 \%$ of patients report wanting their physicians to inquire about their beliefs, most physicians do not do so. ${ }^{3}$ Physicians report feeling uncomfortable discussing religion/spirituality and say they lack proper training and enough time to do so effectively. ${ }^{4} \mathrm{~A}$ critical time to begin closing this gap is in medical school. ${ }^{5}$ Since the early 1990s, medical schools have offered some form of spirituality and health education. ${ }^{6}$ In 1999, the Association of American Medical Colleges published goals and learning objectives on spirituality and health. ${ }^{7}$ These efforts were advanced in 2011 with the publication of expectations for competence in domains of spirituality, aligned with Accreditation Council for Graduate Medical Education competencies. ${ }^{6}$ In 2014, Puchalski and colleagues reported 75\% of U.S. medical schools included spirituality training in their curricula, including topics such as spiritual history taking and the role of health care chaplains. ${ }^{6} \mathrm{We}$ sought to integrate mandatory, longitudinal training on spirituality into our curriculum across all 4 years of medical school. Our team designed an innovative spirituality curriculum based on adult learning theories, including Dewey's principle of continuity and Kolb's cycle of experiential learning. ${ }^{8}$ Here, we report our approach to integrating this prototype training into the core undergraduate medical education (UME) curriculum and initial evaluation of the experience. 


\section{Approach}

In 2014, a team formed at the Icahn School of Medicine at Mount Sinai (ISMMS) to address the need for spirituality and health training in UME. A major challenge was incorporating it into the already packed curriculum. While we encountered no opposition and found stakeholders who valued the topic, prioritizing it and other subject areas simultaneously was taxing. To meet the challenge, we took a 3-pronged approach: establishing and expanding an interprofessional team, engaging in an iterative process and endeavoring to integrate content into existing courses without creating new ones.

\section{Interprofessional team}

A faculty member from the Office of Diversity and Inclusion initially convened a 3-person team: an internal medicine physician and director of the Mount Sinai Human Rights Program (H.G.A.); a general medicine and pediatrics physician and Department of Medical Education faculty member; and himself, a doctoral-level social worker. Over time, the team expanded to include a board-certified chaplain who is an Association for Clinical Pastoral Education (ACPE) certified educator (D.W.F.) and physicians (S. Lerner, S. Leisman), from other specialties such as surgery. Each professional brought a perspective relevant to the overall effort. The physicians understood educational objectives, andragogical methods, and the culture of UME. The chaplain/educator was knowledgeable about day-to-day practices of spiritual care, advances in the growing field of spirituality and health, and adult learning theories. The social worker brought expertise on how spirituality is a social determinant of health and a critical aspect of culturally effective care. In addition, we each acted as a champion for the project in our respective departments. 


\section{Iterative process and integrated curriculum}

We launched the initiative by reviewing the 4-year curriculum to determine where spirituality was being taught. We were guided by the 2011 National Competencies in Spirituality for Medical Education 6 competency areas: health systems, knowledge, patient care, compassionate presence, professional development, and communication. ${ }^{6}$ Following a detailed review of all learning objectives and performance assessments, we determined the only place spirituality was being addressed in the overall curriculum was the first year of the Art and Science of Medicine (ASM) course. ASM is a required 2-year preclinical course providing the knowledge, clinical skills, and professional attitudes essential for clinical practice and includes sustained patient contact across various care settings. In ASM, first-year students have traditionally received a single, 1-hour session on taking a structured spiritual history from a patient.

We then sought to include a module in clinical clerkships that would give students workplacebased learning experience so they could further hone their skills. We consulted clerkship directors (CDs) to determine their interest in working with us to add a clerkship spirituality module. By seeking CDs' input, we hoped to develop highly relevant clinical learning experiences based on realistic dilemmas. We formally presented our aims at a CD group meeting and also sought their feedback via a 27-question needs assessment survey. Overall, CDs indicated that spirituality played an important role in patient care but felt underprepared to teach it. In particular, surgery and psychiatry CDs expressed an interest in working with us to develop a spirituality training module. Because surgeons are less likely to have spirituality discussions with patients ${ }^{9}$ and we had identified a strong partner in our surgical department, we focused on creating a module for the third-year Surgery/Anesthesiology clerkship. Around the same time, ISMMS established the Center for Spirituality and Health and hired a new director of education, 
who is a board-certified chaplain and ACPE certified educator. (While not all medical schools have a center dedicated to spirituality and health, many academic medical centers have departments of spiritual care with whom they partner.) The team invited both him (D.W.F.) and the surgery/anesthesiology clerkship director (S. Lerner) to formally join the effort.

We developed a 1-hour session to help students improve their ability to contribute to spiritually effective care of surgical patients. ${ }^{4}$ We designed this session to follow the Kolb cycle of experiential learning. ${ }^{8}$ Session features include co-facilitation by a surgeon and chaplain/educator to model interprofessional partnerships, guided reflections to explore the impact of spirituality on students' clinical experiences, didactic overviews of key concepts, and surgical case-based discussions. By changing the specific cases utilized for discussion, the session can be generalized to other specialties and care settings.

As part of our discussions, we grappled with how the curriculum might address not only patients' spiritual needs but also engage students' own spiritualities to help mitigate burnout and foster resilience. ${ }^{10}$ Working with the senior associate dean for UME (R.K.), we identified the fourthyear Introduction to Internship (I to I) as suitable course for piloting a small-group reflection process. I to I was considered a good fit as this 2 -week required course focuses on developing skills for internship. The specific aim of our 1-hour session is to help students identify personal sources of meaning and purpose that will assist them in sustaining motivation during the demanding period of residency. We use the Japanese concept of ikigai-meaning "a reason for being"- to provoke discussion on these themes. Since ikigai is not a religious concept/image, it provides a discussion entry point for everyone, regardless of how they identify religiously or spiritually. Session features include facilitation by a chaplain/educator and small-group discussions focused on developing self-awareness and identifying sources of resilience and self- 
care practices.

The final step of integrating spirituality training across the curriculum was redirecting focus on the second year of ASM. Our goal was to provide students with a clinical experience that would reinforce the ASM1 history-taking module and incorporate an interprofessional team experience. This led to creating a spiritual care clinical experience for second-year students, whereby they observe chaplains as active members of the health care team and take spiritual histories. Session features include an initial 30-minute didactic review of the first-year ASM module. Students then pair with a chaplain preceptor and spend 1 to 2 hours observing spiritual care. Students spend another 1 to 2 hours taking patients' spiritual histories and sharing the results with their chaplain preceptors, who follow up with patients to address their spiritual concerns as needed with students observing.

\section{Outcomes}

Between 2014 and 2020, our interprofessional team used an iterative process to integrate competency-linked training on spirituality and health into the required curriculum. Four distinct modules were integrated into 4 existing courses spanning the 4 years of UME (Table 1 ).

We surveyed students about 3 of the modules (Table 2). For ASM2, a 12-question pre-post survey assessed changes in attitude and intentions; for the Surgical/Anesthesiology Clerkship, short-term and long-term surveys assessed impact; and for I to I, a 7-question survey was linked to the learning objectives. Overall, survey responses indicated the curriculum was valuable to student training and professional development.

ForASM2, 48 (74\%) of 65 student responded to the survey. Their answers demonstrated a significant difference in pre-post scores. For the Surgery/Anesthesiology Clerkship, 120 (73\%) of 165 students provided short-term feedback indicating the content was very relevant and the 
session quality was above average. Long-term feedback (15 months) was provided by 105 (64\%) students and indicated that the session positively affected their attitudes about the role of religion/spirituality in medicine and behaviors with patients. For the I to I module, 38 (72\%) of 53 students responded. Results demonstrated, among other findings, that $89 \%$ of respondents "agreed" or "strongly agreed" that as a result of the session, they were able to identify a sense of purpose for becoming a physician; 58\% "agreed" or "strongly agreed" they felt more confident about being an intern; and 76\% "agreed" or "strongly agreed" they would use the concept of ikigai to help sustain purpose and meaning in life.

To assess all 4 modules, we also asked students to respond to open-ended prompts (Table 3). Thematic analysis indicated that most students found the training valuable. The following themes emerged: students appreciated the importance of recognizing patients' spiritual needs; they valued learning about how chaplains are trained, what role they play in patient care, and how to initiate a chaplain consult; and they plan to utilize the FICA tool (faith, importance, community, address; from a spiritual history-taking tool that explores the patient's faith, its importance in their life, their religious/spiritual community, and how to address their faith/beliefs in patient care).

\section{Next Steps}

In undertaking this initiative, we identified 3 key factors-establishing an interprofessional team, working through an iterative process, and integrating the curriculum into existing coursescritical to our success. These factors, along with support from academic administration, worked to address the obstacles we encountered (and other schools may experience): lower prioritization of spirituality training, limited personnel capable of facilitating learning outcomes, and a crowded curriculum. Given these obstacles, we did not attempt to implement a comprehensive 
program on spiritualty all at once. Instead, we found meaningful opportunities in courses where spirituality competencies aligned with existing learning objectives and created specific modules that were easily integrated and led by invested faculty members.

Our initial evaluation of this prototype spirituality training has informed our next steps for expanding and enhancing the curriculum. First, a gap analysis comparing our curriculum to the established competencies indicates a need to focus more attention on 2 of the 6 domains, compassionate presence and professional development. We plan to enhance content accordingly, incorporating additional content on employing medical students' own spiritualties to enhance resilience and reduce burnout. ${ }^{10}$ Second, we plan to develop more granular assessments to refine our evaluation of whether competencies have been met, as well as gather more nuanced outcomes data to determine the curriculum's overall effect on students' perceptions of comfort discussing spirituality with their patients and working collaboratively with a chaplain. Third, we will enhance faculty development to enable faculty to model integrating spirituality into patient management for medical students. Fourth, we are expanding the curriculum on spirituality and health into graduate medical education - initially for the primary care and medicine-pediatrics residents. Fifth, we will investigate medical students' and residents' spirituality as a source of personal resilience.

Our effort to incorporate a spirituality and health curriculum across the continuum of UME underscores our commitment to training young physicians who are highly competent in addressing the full dimension of sickness and wellbeing. Only by integrating the spiritual aspects of health and healing with the physical ones can we offer truly comprehensive, compassionate, and culturally effective patient care, creating a nurturing work environment for the entire health care team. 


\section{References}

1. Pew Research Center. Lipka M, Gecewicz C. More Americans now say they're spiritual but not religious. https://www.pewresearch.org/fact-tank/2017/09/06/more-americans-nowsay-theyre-spiritual-but-not-religious/. Published September 6, 2017. Accessed October $15,2021$.

4. Atkinson HG, Fleenor D, Lerner SM, Poliandro E, Truglio J. Teaching third-year medical students to address patients' spiritual needs in the surgery/anesthesiology clerkship. MedEdPORTAL. 2018;14:10784.

34 Marin DB, Sharma V, Powers R, Fleenor D. Spiritual care and physicians: Understanding spirituality in medical practice. HealthCare Chaplaincy Network. 2017. https://spiritualcareassociation.org/docs/resources/hccn_whitepaper_spirituality_and_phy sicians.pdfAccessed June 6, 2020.

3. Balboni MJ, Sullivan A, Enzinger AC, et al. Nurse and physician barriers to spiritual care provision at the end of life. J Pain Symptom Manage. 2014;48:400-410.

5. Kruizinga R, Scherer-Rath M, Schilderman HJBAM, Puchalski CM, van Laarhoven HHWM. Toward a fully fledged integration of spiritual care and medical care. J Pain Symptom Manage. 2018;55:1035-1040.

6. Puchalski CM, Blatt B, Kogan M, Butler A. Spirituality and health: The development of a field. Acad Med. 2014;89:10-16.

7. Association of American Medical Colleges. Report III: Contemporary Issues in Medicine: Communication in Medicine. Washington, DC: Association of American Medical Colleges; 1999. 
8. Merriam SB, Bierema LL. Adult Learning: Linking Theory and Practice. New York: John Wiley \& Sons; 2014.

9. Rasinski KA, Kalad YG, Yoon JD, Curlin FA. An assessment of U.S. physicians' training in religion, spirituality, and medicine. Med Teach. 2011;33:944-945.

10. Estupiñan B, Kibble J. The relationship between spirituality and burnout in the lives of medical students. Medical Science Educator. 2018;28:37-44. 


\section{Table 1}

Competencies, Objectives, Features, and Assessments for 4 Longitudinal, Integrated Spirituality Training Modules, Icahn School of Medicine at Mount Sinai, 2014-2020

\begin{tabular}{|c|c|c|c|c|}
\hline Component & First year & Second year & Third year & Fourth year \\
\hline $\begin{array}{l}\text { Course in which } \\
\text { spirituality } \\
\text { module occurs }\end{array}$ & $\begin{array}{l}\text { Art and Science of } \\
\text { Medicine 1: } 2 \text {-year pre- } \\
\text { clinical core course that } \\
\text { provides KSAs essential } \\
\text { for clinical practice }\end{array}$ & $\begin{array}{l}\text { Art and Science of } \\
\text { Medicine } 2: 2 \text {-year pre- } \\
\text { clinical core course that } \\
\text { provides KSAs essential } \\
\text { for clinical practice }\end{array}$ & $\begin{array}{l}\text { Surgery/anesthesiology } \\
\text { clerkship: } 8 \text {-week } \\
\text { required clinical clerkship }\end{array}$ & $\begin{array}{l}\text { Introduction to Internship: } \\
\text { 2-week required clerkship } \\
\text { focused on developing } \\
\text { skills for internship }\end{array}$ \\
\hline $\begin{array}{l}\text { Primary } \\
\text { competency } \\
\text { addressed }\end{array}$ & Patient care & $\begin{array}{l}\text { Patient care, } \\
\text { compassionate presence, } \\
\text { and communication }\end{array}$ & $\begin{array}{l}\text { Health systems, } \\
\text { knowledge, patient care, } \\
\text { and communication }\end{array}$ & Professional development \\
\hline $\begin{array}{l}\text { Objectives of } \\
\text { spirituality } \\
\text { training }\end{array}$ & $\begin{array}{l}\text { - Explain the role of } \\
\text { spirituality/religion as } \\
\text { part of culturally } \\
\text { sensitive patient } \\
\text { centered care } \\
\text { - Increase the comfort } \\
\text { level of clinicians with } \\
\text { having conversations } \\
\text { about spirituality and } \\
\text { religion } \\
\text { - Perform a spiritual } \\
\text { history using the FICA } \\
\text { tool } \\
\text { - Recognize the role of } \\
\text { the chaplain as a } \\
\text { member of the } \\
\text { interdisciplinary health } \\
\text { care team }\end{array}$ & $\begin{array}{l}\text { - Describe the role of } \\
\text { spirituality/religion as } \\
\text { part of culturally } \\
\text { sensitive patient } \\
\text { centered care } \\
\text { - Increase the comfort } \\
\text { level of clinicians with } \\
\text { having conversations } \\
\text { about spirituality and } \\
\text { religion } \\
\text { - Practice taking a } \\
\text { spiritual history using } \\
\text { the FICA tool } \\
\text { - Recognize the role of } \\
\text { the chaplain as a } \\
\text { member of the } \\
\text { interdisciplinary health } \\
\text { care team }\end{array}$ & $\begin{array}{l}\text { Discuss the role of } \\
\text { spirituality/religion as } \\
\text { part of culturally- } \\
\text { sensitive, patient- } \\
\text { centered care } \\
\text { - Integrate spirituality in } \\
\text { the perioperative } \\
\text { management of patients } \\
\text { - Elicit a spiritual history, } \\
\text { using the FICA tool as } \\
\text { a model } \\
\text { - Describe the role of } \\
\text { chaplains and how to } \\
\text { effectively } \\
\text { communicate with them } \\
\text { to improve patient care }\end{array}$ & $\begin{array}{l}\text { - Define physician } \\
\text { burnout } \\
\text { - Recall a personal } \\
\text { experience of burnout } \\
\text { as a medical student } \\
\text { - Identify one motivation } \\
\text { for becoming a } \\
\text { physician } \\
\text { - Express one's purpose } \\
\text { for becoming a } \\
\text { physician } \\
\text { - Define the Japanese } \\
\text { concept of ikigai } \\
\text { - Apply the concept of } \\
\text { ikigai to identify } \\
\text { personal sources of } \\
\text { meaning and purpose }\end{array}$ \\
\hline
\end{tabular}




\begin{tabular}{|c|c|c|c|c|}
\hline & $\begin{array}{l}\text { Explain the various } \\
\text { ways of making a } \\
\text { spiritual care consult }\end{array}$ & $\begin{array}{l}\text { Explain the various } \\
\text { ways of making a } \\
\text { spiritual care consult }\end{array}$ & & \\
\hline $\begin{array}{l}\text { Features of the } \\
\text { spirituality } \\
\text { training }\end{array}$ & $\begin{array}{l}\text { - A chaplain/educator } \\
\text { gives 45-min. lecture on } \\
\text { taking a spiritual history } \\
\text { - A chaplain/educator } \\
\text { facilitates a 60-min. } \\
\text { discussion on spirituality } \\
\text { in medicine with an } \\
\text { interprofessional panel } \\
\text { comprised of a chaplain, } \\
\text { surgeon, social worker, } \\
\text { and a patient or family } \\
\text { member }\end{array}$ & $\begin{array}{l}\text { - Students watch a video } \\
\text { of a physician taking a } \\
\text { spiritual history } \\
\text { - Students practice } \\
\text { eliciting spiritual } \\
\text { histories from patients } \\
\text { under a chaplain's } \\
\text { supervision } \\
\text { - Students observe a } \\
\text { member of chaplain } \\
\text { team providing spiritual } \\
\text { care }\end{array}$ & $\begin{array}{l}\text { - A surgeon and a } \\
\text { chaplain/educator co- } \\
\text { facilitate a session in } \\
\text { which students reflect } \\
\text { and explore the impact } \\
\text { of their own and } \\
\text { patients' spirituality on } \\
\text { their clinical } \\
\text { experiences; the } \\
\text { surgeon and chaplain } \\
\text { give a brief didactic } \\
\text { overview of key } \\
\text { concepts; and the entire } \\
\text { group discusses cases } \\
\text { involving spiritual } \\
\text { issues/dilemmas }\end{array}$ & $\begin{array}{l}\text { - A chaplain/educator } \\
\text { facilitates small group } \\
\text { discussions in which 4-8 } \\
\text { students reflect on the } \\
\text { definition and } \\
\text { prevalence of burnout; } \\
\text { their motivations for } \\
\text { becoming a physician } \\
\text { and whether they } \\
\text { consider medicine a } \\
\text { calling; identification of } \\
\text { internal resources that } \\
\text { they can utilize during } \\
\text { professional challenges; } \\
\text { the Japanese concept of } \\
\text { ikigai, what makes a } \\
\text { "life worth living" }\end{array}$ \\
\hline $\begin{array}{l}\text { Performance } \\
\text { assessments }\end{array}$ & $\begin{array}{l}\text { - Checklist evaluation } \\
\text { live/recorded } \\
\text { performance } \\
\text { - Objective structured } \\
\text { clinical exams }\end{array}$ & $\begin{array}{l}\text { - Checklist evaluation } \\
\text { live/recorded } \\
\text { performance } \\
\text { - Objective structured } \\
\text { clinical exams } \\
\text { - Assessment/pastoral care } \\
\text { - Feedback or evaluation } \\
\text { by faculty/mentor/ } \\
\text { - preceptor/expert }\end{array}$ & $\begin{array}{l}\text { - Feedback or } \\
\text { evaluation/self }\end{array}$ & $\begin{array}{l}\text { - Feedback or } \\
\text { evaluation/self }\end{array}$ \\
\hline
\end{tabular}

Abbreviations: KSA, knowledge, skills, and attitudes; FICA, faith, importance, community, address (from a spiritual history-taking tool that explores the patient's faith, its importance in their life, their religious/spiritual community, and how to address their faith/beliefs in patient care). 


\section{Table 2}

Student Responses to Surveys About 4 Longitudinal, Integrated Spirituality Training Modules, Icahn School of Medicine at Mount Sinai, 2014-2020

\begin{tabular}{|c|c|c|c|c|c|c|c|c|c|c|}
\hline Pre-question & Mean & Median & SD & SE & Post-question & Mean & Median & SD & SE & $P$ value \\
\hline \multicolumn{11}{|l|}{$\begin{array}{l}\text { Second-year Art and Science of } \\
\text { Medicine course: retrospective } \\
\text { pre/post-session }(n=48)^{\mathrm{a}}\end{array}$} \\
\hline $\begin{array}{l}\text { Prior to your chaplain } \\
\text { experience, to what degree did } \\
\text { you agree with the following } \\
\text { statement? Religion and } \\
\text { spirituality can help patients } \\
\text { cope with their illness. }\end{array}$ & 4.29 & 4.00 & 0.77 & 0.11 & $\begin{array}{l}\text { After your chaplain experience, } \\
\text { to what degree did you agree } \\
\text { with the following statement? } \\
\text { Religion and spirituality can } \\
\text { help patients cope with their } \\
\text { illness. }\end{array}$ & 4.58 & 5.00 & 0.71 & 0.10 & .0005 \\
\hline $\begin{array}{l}\text { Prior to your chaplain } \\
\text { experience, to what degree did } \\
\text { you agree with the following } \\
\text { statement? Patient's religious or } \\
\text { spiritual history should be a part } \\
\text { of the medical history. }\end{array}$ & 3.71 & 4.00 & 0.68 & 0.10 & $\begin{array}{l}\text { After your chaplain experience, } \\
\text { to what degree did you agree } \\
\text { with the following statement? } \\
\text { Patient's religious or spiritual } \\
\text { history should be a part of the } \\
\text { medical history. }\end{array}$ & 4.23 & 4.00 & 0.72 & 0.10 & $<.0001$ \\
\hline $\begin{array}{l}\text { Prior to your chaplain } \\
\text { experience, to what degree did } \\
\text { you agree with the following } \\
\text { statement? Patients have } \\
\text { religious or spiritual beliefs that } \\
\text { would influence their medical } \\
\text { decisions if they become gravely } \\
\text { ill. }\end{array}$ & 4.21 & 4.00 & 0.65 & 0.09 & $\begin{array}{l}\text { After your chaplain experience, } \\
\text { to what degree did you agree } \\
\text { with the following statement? } \\
\text { Patients have religious or } \\
\text { spiritual beliefs that would } \\
\text { influence their medical } \\
\text { decisions if they become } \\
\text { gravely ill. }\end{array}$ & 4.52 & 5.00 & 0.58 & 0.08 & .0003 \\
\hline $\begin{array}{l}\text { Prior to your chaplain } \\
\text { experience, to what degree did } \\
\text { you agree with the following }\end{array}$ & 2.7 & 3.00 & 0.97 & 0.14 & $\begin{array}{l}\text { After your chaplain experience, } \\
\text { to what degree did you agree } \\
\text { with the following statement? I }\end{array}$ & 4.42 & 4.00 & 0.54 & 0.08 & $<.0001$ \\
\hline
\end{tabular}


statement? I understand the role of a hospital chaplain.

Prior to your chaplain experience, to what degree did you agree with the following statement? I am comfortable taking a spiritual history.

N/A

N/A

\section{Third-year surgery/anesthesiology clerkship: immediate post-session survey $(n=120)$}

$\begin{array}{llllllllllll}\text { N/A } & \text { N/A } & \text { N/A } & \text { N/A } & \text { N/A } & \text { Overall session quality } & 4.15 & 4.00 & .75 & .07 & \text { N/A } \\ \text { N/A } & \text { N/A } & \text { N/A } & \text { N/A } & \text { N/A } & \begin{array}{l}\text { Session's relevance to patient } \\ \text { care }^{\text {c }}\end{array} & 2.70 & 3.00 & .50 & .05 & \text { N/A }\end{array}$

Third-year surgery/anesthesiology clerkship: longer term impact survey $(n=105)$

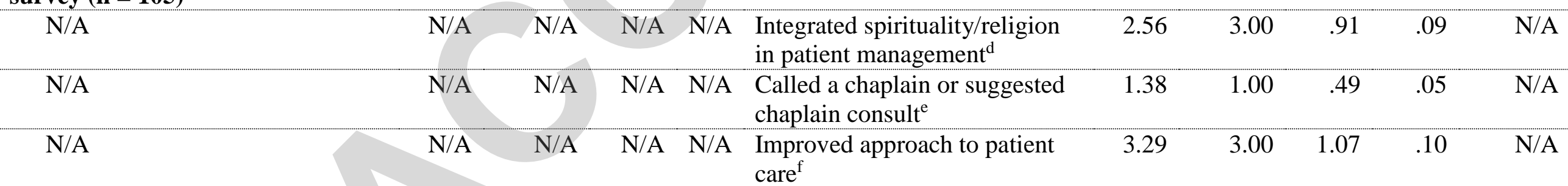

\section{Fourth-year introduction to} care understand the role of a hospital chaplain.

After your chaplain experience,

4.25

$\begin{array}{llll}4.00 & 0.76 & 0.11 & <.0001\end{array}$

with the following statement? I am comfortable taking a spiritual history.

After your chaplain experience,

how likely are you to

incorporate the FICA tool into

your physical and history?

After your chaplain experience,

4.46

5.00

how likely are you to make a

referral to a hospital chaplain?

\section{internship: post-session survey}

$(\mathbf{n}=38)^{\mathrm{a}}$ 


\begin{tabular}{|c|c|c|c|c|c|c|c|c|c|c|}
\hline N/A & N/A & N/A & N/A & N/A & $\begin{array}{l}\text { As a result of this session, I } \\
\text { know more about burnout }\end{array}$ & 3.97 & 4.00 & 0.85 & 0.14 & N/A \\
\hline N/A & N/A & N/A & N/A & N/A & $\begin{array}{l}\text { As a result of this session, I was } \\
\text { able to identify a time when I } \\
\text { experienced burnout as a } \\
\text { medical student }\end{array}$ & 4.26 & 4.00 & 0.89 & 0.14 & N/A \\
\hline N/A & N/A & N/A & N/A & N/A & $\begin{array}{l}\text { As a result of this session, I was } \\
\text { able to identify at least one } \\
\text { thing that motivates me to be a } \\
\text { physician }\end{array}$ & 4.55 & 5.00 & 0.76 & 0.12 & N/A \\
\hline N/A & N/A & N/A & N/A & N/A & $\begin{array}{l}\text { As a result of this session, I was } \\
\text { able to identify a sense of } \\
\text { purpose for becoming a } \\
\text { physician }\end{array}$ & 4.29 & 4.00 & 0.84 & 0.14 & N/A \\
\hline N/A & N/A & N/A & N/A & N/A & $\begin{array}{l}\text { As a result of this session, I feel } \\
\text { more confident about being an } \\
\text { intern next year }\end{array}$ & 3.63 & 4.00 & 1.15 & 0.19 & N/A \\
\hline N/A & N/A & N/A & N/A & N/A & $\begin{array}{l}\text { As a result of this session, I } \\
\text { know more about the Japanese } \\
\text { concept of ikigai }\end{array}$ & 4.66 & 5.00 & 0.75 & 0.12 & N/A \\
\hline N/A & N/A & N/A & N/A & N/A & $\begin{array}{l}\text { As a result of this session, I will } \\
\text { use the concepts in ikigai to } \\
\text { help me sustain purpose and } \\
\text { meaning in life }\end{array}$ & 3.97 & 4.00 & 0.97 & 0.16 & N/A \\
\hline
\end{tabular}

Abbreviations: N/A, not applicable; FICA, faith, importance, community, address (from a spiritual history-taking tool that explores the patient's faith, its importance in their life, their religious/spiritual community, and how to address their faith/beliefs in patient care).

${ }^{\mathrm{a}}$ On a scale of $1-5$ where $1=$ strongly agree, $5=$ strongly disagree.

${ }^{\mathrm{b}}$ On a scale of $1-5$ where $1=$ poor, $5=$ excellent.

'On a scale of $1-3$ where $1=$ not relevant, $3=$ very relevant.

${ }^{\mathrm{d}}$ On a scale of $1-5$ where $1=$ never, $5=$ almost always.

${ }^{\mathrm{e} O n}$ a scale of $1-2$ where $1=$ no, $5=$ yes.

${ }^{\mathrm{f}}$ On a scale of $1-5$ where $1=$ not at all, $5=$ great extent. 


\section{Table 3}

Qualitative Feedback Themes, From 4 Longitudinal, Integrated Spirituality Training Modules, Icahn School of Medicine at Mount Sinai, 2014-2020

$\begin{array}{ll}\text { Importance of spirituality } & \begin{array}{l}\text { Sefinition/explanation } \\ \text { was important to address and expressed } \\ \text { appreciation for the positive impact that } \\ \text { spirituality can have in patient care. }\end{array}\end{array}$

Sample comments

- "I think this is such a wonderful opportunity for medical students because it teaches us how to be patient-centered and how to provide humanistic care-patients are humans with spiritual needs that should be addressed like any other medical need."

- "Experiencing the role of religion/spirituality with patients is very different than just hearing about it in a large lecture. It allowed me to take a refreshing step back from the medical aspect and connect with patients on a much more meaningful level, which is imperative to being a wellrounded physician."

Usefulness of FICA Students indicated that the FICA tool provides an easy-to-use framework for spiritual-history taking and planned to

- "It was very helpful to learn about [the] FICA tool for addressing patients' spiritual needs."

- "Taught me how to get a good spiritual history and how to ask open ended questions."

Role of chaplains utilize it in their patient care.

- "[My preceptor] made me feel so comfortable talking about religion with patients when that isn't something big in my own life. I really gained a huge appreciation for the chaplains and had a wonderful experience."

- "This was an excellent clinical site placement. I really feel like I walked away with a much better understanding of the role of hospital chaplains and how we can better utilize the important services/ contributions they provide patients."

Abbreviation: FICA, faith, importance, community, address (from a spiritual history-taking tool that explores the patient's faith, its importance in their life, their religious/spiritual community, and how to address their faith/beliefs in patient care). 